\title{
Partition of Nitrogen Excretion in Urine and the Feces of Holstein Replacement Heifers
}

\author{
J. C. Marini ${ }^{1}$ and M. E. Van Amburgh ${ }^{2}$ \\ ${ }^{1}$ Department of Animal Sciences, University of Illinois, Urbana 61801 \\ ${ }^{2}$ Animal Sciences Department, Cornell University, Ithaca, NY 14853.
}

\begin{abstract}
Increasing public concern has been focused on animal production systems as a major nonpoint source of pollution. These studies were conducted to further our understanding of whole-animal $\mathrm{N}$ metabolism, $\mathrm{N}$ excretion, and its partition between feces and urine in growing dairy heifers. Isocaloric diets [2.31 Mcal of metabolizable energy $(\mathrm{ME}) / \mathrm{kg}$ of dry matter $(\mathrm{DM})$ ], ranging from 12.4 to $34.2 \mathrm{~g}$ of N/kg of DM, were fed to Holstein heifers in 2 experiments at approximately 1.8 times maintenance. Diets were formulated to provide 54 to $143 \%$ of the ruminal ammonia requirements as predicted by the Cornell Net Carbohydrate and Protein System. Increasing the $\mathrm{N}$ content of the diet increased urinary $\mathrm{N}$ excretion and $\mathrm{N}$ balance, but did not affect fecal $\mathrm{N}$ excretion. Holstein heifers fed low $\mathrm{N}$ diets were able to maintain growth rates consistent with current recommendations while at the same time reducing $\mathrm{N}$ excretion, in particular nitrogenous compounds that are readily converted to ammonia. However, more research is needed before this type of diet is recommended for growing heifers because of possible changes in body composition that may affect future milk production and performance.
\end{abstract}

(Key words: manure, nitrogen, replacement heifer)

Abbreviation key: $\mathbf{M E}=$ metabolizable energy, $\mathbf{P D}=$ purine derivative, $\mathbf{P U N}=$ plasma urea $\mathrm{N}, \mathbf{U N}=$ urinary $\mathrm{N}, \mathbf{U U N}=$ urinary urea $\mathrm{N}$.

\section{INTRODUCTION}

Ruminant animals have evolved to digest fibrous, low quality forages in their foregut, where the ruminal microbiota is able to break cellulolytic bonds and provide energy for their growth and the host (Van Soest, 1994). Ruminants are able to recycle large quantities of $\mathrm{N}$ into the rumen, instead of excreting it in the urine, thus supplying bacteria with its need for ammonia (Marini and Van Amburgh, 2003). Because energy is the most

Received October 1, 2004.

Accepted January 31, 2005.

Corresponding author: J. C. Marini; e-mail: jcmarini@uiuc.edu. expensive component of the diet under modern intensive feeding conditions, CP, and particularly degradable protein, is usually in excess, and the ability of ruminants to recycle $\mathrm{N}$ is not fully exploited. Increasing public concern has been focused on animal production systems as a major nonpoint source of pollution, which has spurred research aimed to reduce $\mathrm{N}$ excretion. Nutrient losses may affect ground and surface water quality; in addition, ammonia and nitrous oxide emissions can affect air quality, and the latter has been implicated as a significant contributor to global warming, having a 310× more harmful mass-specific effect than $\mathrm{CO}_{2}$ as a global warming agent (IPCC, 1996).

Current research in handling (Swensson and Gustafsson, 2002), storage (Nicholson et al., 2002), and application (Wulf et al., 2002) of manure has shown that it is possible to reduce ammonia losses from manure, but because a large proportion of ammonia is volatilized before it reaches a storage facility, preventive measures seem to be more effective (Muck and Steenhuis, 1980).

Different schemes to reduce $\mathrm{N}$ excretion and increase efficiency of $\mathrm{N}$ use in cattle have been evaluated. Some involve the use of metabolism modifiers, such as recombinant bST (Johnson et al., 1992) or $\beta$-agonists (Sillence et al., 2000). Others attempted dietary manipulation, such as feeding oscillating protein concentrations (Cole et al., 2003), reducing the protein degraded in rumen (Tomlinson et al., 1997), or supplementing with undegradable protein and crystalline amino acids (Krober et al., 2000).

Although numerous studies on $\mathrm{N}$ excretion have been conducted recently in lactating dairy cattle (Castillo et al., 2001; Kulling et al., 2001; Frank et al., 2002), very few have been done in replacement heifers. Because glucogenic amino acids can partially fulfill the large demand of glucogenic precursors for the synthesis of milk lactose, dairy cows have requirements for amino acid in excess of their need for protein synthesis (Drackley et al., 2001). Alternatively, replacement heifers can be fed to achieve a breeding weight at different ages, allowing for greater dietary manipulation than lactating cows. Further, because replacement heifers constitute a large proportion of the dairy herd, approximately $45 \%$ of the number of milking cows (Economic Research Service, 2002), any 


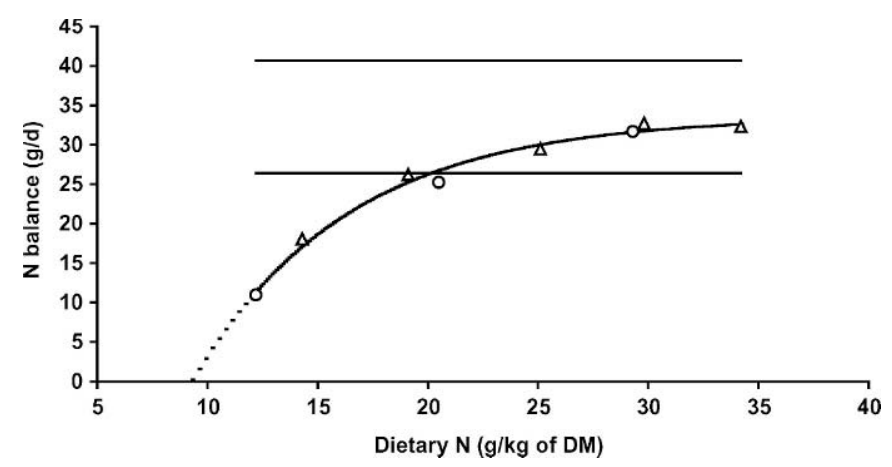

Figure 1. Effect of dietary $\mathrm{N}(\mathrm{g} / \mathrm{kg}$ of $\mathrm{DM})$ on the $\mathrm{N}$ balance of Holstein heifers. The prediction equation was $\mathrm{N}$ balance $(\mathrm{g} / \mathrm{d})=33.5$ $-125.1 \mathrm{e}^{(-0.142 \times \mathrm{N})} ; \mathrm{r}^{2}=0.95$. Horizontal lines denote the $95 \%$ confidence interval for the plateau. Each symbol represents the mean of 4 observations (experiment $1, \triangle$; experiment $2, \bigcirc$ ). $\mathrm{SEM}=3.4 \mathrm{~g} / \mathrm{d}$.

reduction in their $\mathrm{N}$ excretion will have an impact at the farm level.

These studies were conducted to further our understanding of whole-animal $\mathrm{N}$ metabolism, $\mathrm{N}$ excretion, and its partition between feces and urine when highly fermentable isocaloric diets, varying in $\mathrm{N}$ (protein) content, are offered to growing Holstein heifers. A better understanding of whole-animal $\mathrm{N}$ metabolism will allow nutritionists to optimize growth performance while minimizing $\mathrm{N}$ excretion.

\section{MATERIALS AND METHODS}

\section{Animals and Diets}

Diets were formulated using the Cornell Net Carbohydrate and Protein System (Fox et al., 2004) to provide increasing levels of dietary $\mathrm{N}$ and sufficient metabolizable energy (ME) to achieve an average daily gain of $\sim 1.0 \mathrm{~kg}$ and a $\mathrm{N}$ retention of $\sim 30 \mathrm{~g} / \mathrm{d}$ (Figure 1 ). The model predicted that the $\mathrm{N}$ requirement for $\mathrm{ME}$ allowable gain was $29.0 \mathrm{~g}$ of N/d. Diets, consisting of $30 \%$ brome hay and $70 \%$ concentrate, were formulated to be isocaloric on a ME basis (2.31 Mcal/kg of DM), to provide vitamins and minerals in accordance with current guidelines (NRC, 2001), and to contain similar concentrations of NDF $(\sim 32 \%)$ and soluble protein $(\sim 30 \%)$, which was accomplished by substituting soybean meal with citrus pulp and urea. Diets have been described in detail elsewhere (Marini and Van Amburgh, 2003). Briefly, there were 2 pelleted feeds [pellet A: $28.6 \%$ corn, $14.3 \%$ molasses, and $57.1 \%$ citrus pulp ( $15.5 \mathrm{~g}$ of $\mathrm{N} / \mathrm{kg}$ of $\mathrm{DM}$ ); pellet B: $21.5 \%$ corn, $13.4 \%$ molasses, $26.9 \%$ citrus pulp, $37 \%$ soybean meal, and $1.2 \%$ urea (43.5 g of $\mathrm{N} / \mathrm{kg}$ of DM)], and by mixing them in specific proportions, the nutrient concentrations for the different diets was obtained. Urea was included to maintain a constant proportion of soluble protein.

Each experimental period was $21 \mathrm{~d}$ long and included a 15-d adaptation to the diet, a 5-d total collection of fecal and urinary excretions, and a final day when blood was sampled.

Experiment 1. Four Holstein heifers (initial BW, 204 $\pm 2 \mathrm{~kg}$; final BW, $326 \pm 4 \mathrm{~kg}$ ) fitted with rumen cannulae were used in a Youden-square design ( 5 periods and 5 treatments) to investigate the effect of dietary $\mathrm{N}$ concentration on $\mathrm{N}$ metabolism and excretion. Results from urea kinetics using stable isotopes in these animals have been previously published (Marini and Van Amburgh, 2003). Heifers were individually fed every $2 \mathrm{~h}$ using automatic feeders at approximately $95 \%$ of ad libitum intake $\left(90 \mathrm{~g}\right.$ of $\mathrm{DM} / \mathrm{kg}$ of $\left.\mathrm{BW}^{0.75}\right)$ Diets were sampled daily on the last week of each period, composited by weight, and subsequently analyzed. The actual $\mathrm{N}$ content of the diets is reported in Table 1. Animals had access to water at all times. Animals were weighed without feed or water restriction every week on 2 consecutive $\mathrm{d}$.

Experiment 2. Four Holstein heifers (initial BW, 184 $\pm 3 \mathrm{~kg}$; final BW, $237 \pm 11 \mathrm{~kg}$ ) were used in a $3 \times 3$ Latin square with an extra replication (3 periods and 3 treatments) in a subsequent study. The primary composition of pellets A and B were identical to those in experiment 1 . However, the ingredients used for the pelleted feed had a lower $\mathrm{N}$ content, and, as a result, diets in experiment 2 had lower $\mathrm{N}$ content than planned. The actual $\mathrm{N}$ content of the diets is reported in Table 1. Animals were fed individually every $2 \mathrm{~h}$ using automatic feeders and at the same intake level $(90 \mathrm{~g}$ of $\mathrm{DM} / \mathrm{kg}$ of $\mathrm{BW}^{0.75}$ ) as in experiment 1.

Care, handling, and sampling of the heifers were in accordance with the guidelines issued by the Cornell University Animal Care and Use Committee. Heifers were housed at the Large Animal Research and Teaching Unit in individual metabolism stalls in a temperaturecontrolled environment $\left(18\right.$ to $20^{\circ} \mathrm{C}$ ) under continuous lighting and background noise. Animals were allowed to exercise individually for $5 \mathrm{~h}$ in a $25-\mathrm{m}^{2}$ pen twice weekly.

\section{Sample Collection}

Feces and urine were collected daily between $\mathrm{d} 16$ and 20 of each experimental period before the 0800 -h feeding and were weighed to determine output; a $1 \%$ subsample of urine and a $3 \%$ subsample of feces were collected, composited by period, and stored at $-20^{\circ} \mathrm{C}$ until later analysis. Urine was collected from the bladder with a 22gauge Foley catheter (Bard Medical Division, Covington, GA) into a plastic container with $200 \mathrm{~mL}$ of $50 \% \mathrm{H}_{2} \mathrm{SO}_{4}$ 
Table 1. The N content, Cornell Net Carbohydrate and Protein System (CNCPS)-predicted ruminal peptide and ammonia balances, and $\mathrm{N}$ retention for the treatment diets.

\begin{tabular}{|c|c|c|c|c|c|}
\hline \multirow[b]{2}{*}{ Item } & \multicolumn{5}{|c|}{ Experiment 1} \\
\hline & E1D $1^{1}$ & E1D2 & E1D3 & E1D4 & E1D5 \\
\hline $\mathrm{N}$ content, $\mathrm{g} / \mathrm{kg}$ of $\mathrm{DM}$ & 14.4 & 19.0 & 25.1 & 29.8 & 34.2 \\
\hline Peptide balance, ${ }^{2} \%$ & 33 & 56 & 81 & 108 & 138 \\
\hline Ammonia balance, ${ }^{2} \%$ & 60 & 74 & 89 & 110 & 142 \\
\hline \multirow[t]{3}{*}{$\mathrm{N}$ retention, ${ }^{2} \mathrm{~g} / \mathrm{d}$} & 29 & 30 & 30 & 31 & 30 \\
\hline & & \multicolumn{4}{|c|}{ Experiment 2} \\
\hline & & E2D1 & \multicolumn{2}{|c|}{ E2D3 } & E2D5 \\
\hline $\mathrm{N}$ content, $\mathrm{g} / \mathrm{kg}$ of $\mathrm{DM}$ & & 12.4 & \multicolumn{2}{|c|}{20.5} & 29.3 \\
\hline Peptide balance, ${ }^{2} \%$ & & 27 & \multicolumn{2}{|c|}{66} & 105 \\
\hline Ammonia balance, ${ }^{2} \%$ & & 54 & \multicolumn{2}{|c|}{80} & 107 \\
\hline $\mathrm{N}$ retention, ${ }^{2} \mathrm{~g} / \mathrm{d}$ & & 25 & \multicolumn{2}{|c|}{27} & 28 \\
\hline
\end{tabular}

${ }^{1} \mathrm{E} i \mathrm{D} j=$ Diet $i$ in experiment $j$.

${ }^{2}$ Calculated with CNCPS v 4.0 (Fox et al., 2000).

to reduce $\mathrm{pH}$ to $<2.5$. An additional urine subsample was collected daily, immediately diluted, and stored at $-20^{\circ} \mathrm{C}$ for analysis of purine derivatives (PD), a marker of ruminal bacteria production.

On d 21, ruminal fluid (experiment 1) and blood were sampled 10, 50, and 90 min after the 1000 -h meal to portray a 2 -h feeding period. Ruminal fluid $\mathrm{pH}$ was measured immediately (Accumet $\mathrm{pH}$ meter model 620; Fisher Scientific, Pittsburgh, PA), and an aliquot was acidified with $50 \% \mathrm{H}_{2} \mathrm{SO}_{4}$ to prevent the loss of ammonia. Blood was collected from the jugular vein into Vacutainers containing heparin (Becton Dickinson, Rutherford, NJ). Samples were placed on ice and centrifuged for 15 min at $1500 \times g$ to obtain plasma or clear ruminal fluid.

\section{Sample Analysis}

Feed, fecal (fresh feces), and urinary $\mathrm{N}$ (UN) were measured by macro Kjeldahl (AOAC, 1990) that was modified to include the use of boric acid and steam distillation (Pierce and Haenisch, 1940). Dry matter determination was done by oven-drying at $105^{\circ} \mathrm{C}$ for $72 \mathrm{~h}$. Feed and fecal NDF and ADF were analyzed using the method of Van Soest et al. (1991) with the addition of sulfite for NDF determination. The NDF and ADF residues were analyzed for $\mathrm{N}$ content by macro Kjeldahl (AOAC, 1990). Fecal ammonia was steam-distilled with $\mathrm{MgO}$, collected in boric acid, and titrated with $0.1 \mathrm{~N}$ $\mathrm{HCl}$. Fecal nucleic acids were determined following the procedure of Zinn and Owens (1986).

Plasma (PUN) and urinary urea N (UUN) were determined by the diacetyl monoxime method of Marsh et al. (1957) using a Technicon autoanalyzer (Technicon Instruments Corporation, Tarrytown, NY). Non-UUN was determined by difference between UN and UUN. Urinary ammonia $\mathrm{N}$ was measured using the Berthelot reaction (Chaney and Marbach, 1962). Urinary creatinine was determined by the Jaffe reaction with a commercial kit (Sigma 555-A; Sigma, St. Louis, MO). Purine derivatives were measured in urine by reverse-phase HPLC (Beckman System Gold; Beckman Instruments, Palo Alto, CA) according to the method of Shingfield and Offer (1999).

\section{Statistical Analyses}

Data were analyzed using the MIXED procedure of SAS (SAS Inst., Inc., Cary, NC). The Youden- (experiment 1) and Latin- (experiment 2) square designs had treatment and period as fixed effects and animal as a random effect. Experiments 1 and 2 were analyzed individually, and because no study difference was found for any of the variables analyzed, data from experiments 1 and 2 were pooled, and linear and quadratic polynomial contrasts were analyzed. Least squares means are reported; degrees of freedom were calculated with the Satterthwaite option and used to calculate the standard error of the mean. Theoretical considerations suggest an upper asymptotic relationship between $\mathrm{N}$ intake and $\mathrm{N}$ balance (Flodin et al., 1977; Mercer et al., 1989) as well as for $\mathrm{N}$ intake and N, DM, and NDF digestibilities. Thus, the following model was fitted when data departure from linearity using PROC NLIN of SAS:

$$
\mathrm{Y}=\mathrm{a}+\mathrm{b} \times \mathrm{e}^{(\mathrm{c} \times \mathrm{N})}
$$

where e is the base of the natural logarithms, and $\mathrm{N}$ is the $\mathrm{N}$ content of the diet ( $\mathrm{g} / \mathrm{kg}$ of $\mathrm{DM})$. The coefficient of determination $\left(\mathrm{r}^{2}\right)$ was estimated as

$$
\mathrm{r}^{2}=1-(\mathrm{RSS} / \mathrm{CTSS})
$$



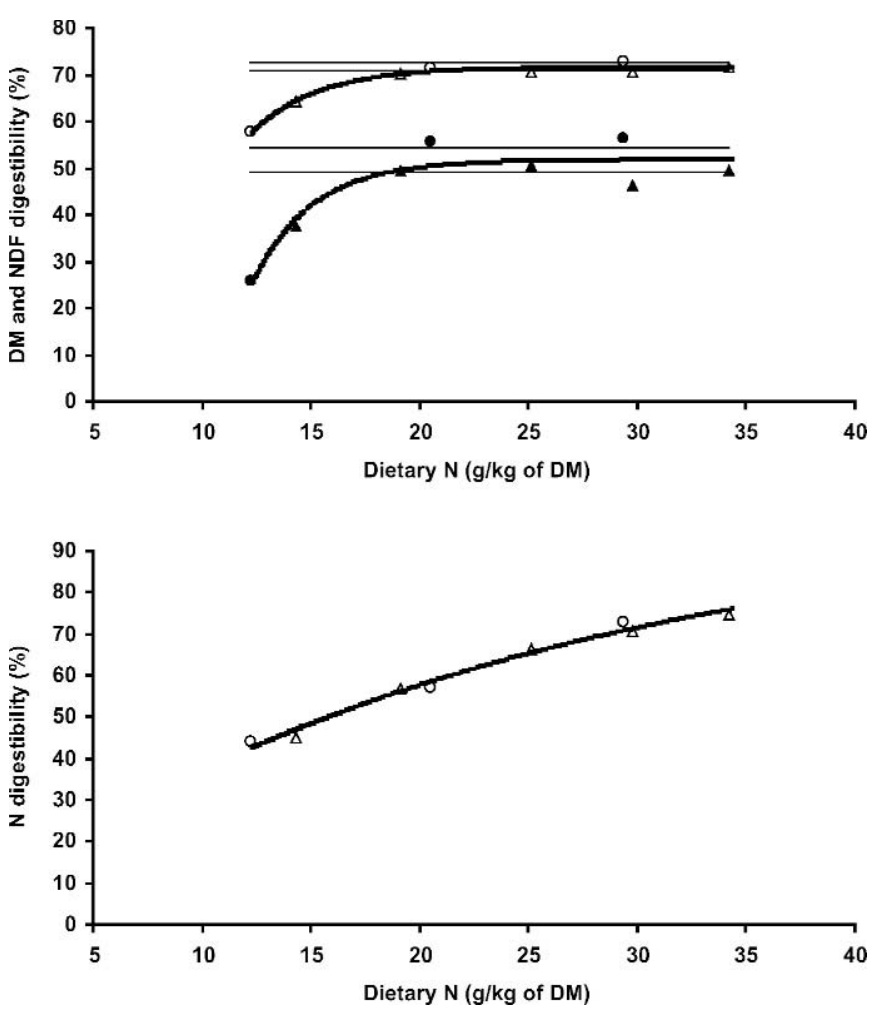

Figure 2. Effect of dietary $\mathrm{N}(\mathrm{g} / \mathrm{kg}$ of $\mathrm{DM})$ on $\mathrm{DM}(\triangle, \bigcirc)$ and NDF digestibilities ( $\boldsymbol{\Delta}, \boldsymbol{\bullet}$; panel $\mathrm{A}$ ) and on $\mathrm{N}$ digestibilities (panel $\mathrm{B}$ ). The prediction equations were DM digestibility $(\%)=71.7-731 \mathrm{e}^{(-0.32 \times}$ $\mathrm{N}) ; \mathrm{r}^{2}=0.99$; NDF digestibility $(\%)=51.8-2227 \mathrm{e}^{(-0.36 \times \mathrm{N})}, \mathrm{r}^{2}=0.99$; and $\mathrm{N}$ digestibility $(\%)=100.8-93.4 \mathrm{e}^{(-0.039 \mathrm{~N})} ; \mathrm{r}^{2}=0.94$. Horizontal lines denote the $95 \%$ confidence interval for the plateau. Each symbol represents the mean of 4 observations (experiment 1, $\triangle, \boldsymbol{\Delta}$; experiment $2, \bigcirc, 0$ ). The SEM were $0.80,2.04$, and $1.49 \%$ for DM, NDF, and $\mathrm{N}$ digestibility, respectively.

where RSS is the residual sum of squares, and CTSS is the corrected total sum of squares (Han et al., 2000).

\section{RESULTS}

Increasing the $\mathrm{N}$ content of the diet increased $\mathrm{N}$ balance curvilinearly (Figure 1a) as shown in the following equation:

$$
\mathrm{N} \text { balance }(\mathrm{g} / \mathrm{d})=33.5-125.1 \times \mathrm{e}^{(-0.142 \times \mathrm{N})} ; \mathrm{r}^{2}=0.95 \text {. }
$$

The asymptotic value of the equation $(33.5 \pm 3.5 \mathrm{~g}$ of $\mathrm{N} /$ $\mathrm{kg}$ of $\mathrm{DM}$ ) indicates the maximal $\mathrm{N}$ retention when $\mathrm{N}$ content of the diet was not limiting. The $95 \%$ coefficient interval of the asymptote indicates that a diet with 20.1 $\mathrm{g}$ of $\mathrm{N} / \mathrm{kg}$ of $\mathrm{DM}$ resulted in a $\mathrm{N}$ retention that was not statistically different than the plateau. However, plateau values were reached at $\sim 30 \mathrm{~g}$ of $\mathrm{N} / \mathrm{kg}$ of DM. Weight gains did not show a linear $(P=0.41)$ nor a quadratic $(P=0.35)$ response to dietary $\mathrm{N}$ content and

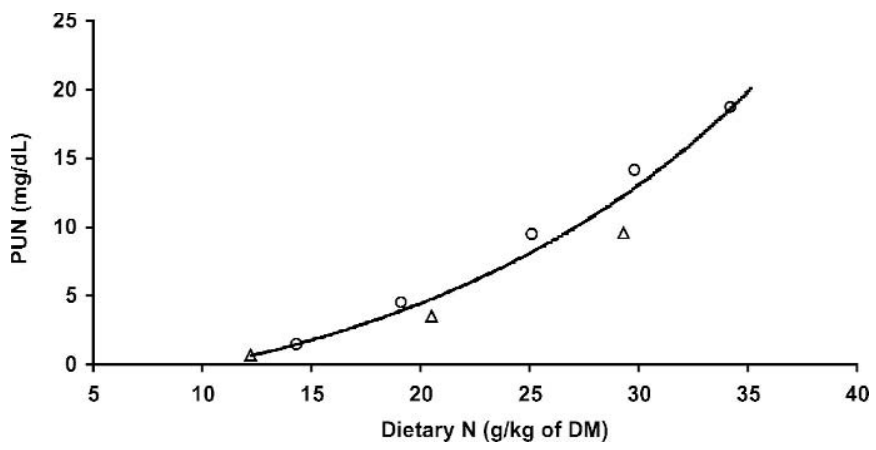

Figure 3. Effect of dietary $\mathrm{N}(\mathrm{g} / \mathrm{kg}$ of $\mathrm{DM})$ on plasma urea $\mathrm{N}$ (PUN) of Holstein heifers. Each symbol represents the mean of 4 observations (experiment $1, \triangle$; and experiment $2, \bigcirc$ ). The prediction equation was PUN $(\mathrm{mg} / \mathrm{dL})=-5.54+2.90 \times \mathrm{e}^{(0.062 \mathrm{~N})} ; \mathrm{r}^{2}=0.89 . \mathrm{SEM}=$ $0.99 \mathrm{mg} / \mathrm{dL}$.

averaged $0.93 \pm 0.05 \mathrm{~kg} / \mathrm{d}$. Relatively large changes in BW can result after defecation, urination, or drinking water, that together with the small number of animals used, prevented the finding of differences among the treatment diets. Weight gains, however, were consistent with the measured $\mathrm{N}$ balances $(25.8 \pm 1.7 \mathrm{~g}$ of $\mathrm{N} / \mathrm{d})$.

Total tract DM and NDF digestibilities showed a curvilinear relationship with $\mathrm{N}$ intake (Figure 2a):

$$
\begin{gathered}
\operatorname{DMdig}(\%)=71.7-731 \times \mathrm{e}^{(-0.32 \times \mathrm{N})} ; \mathrm{r}^{2}=0.99 \\
\operatorname{NDFdig}(\%)=51.8-2227 \times \mathrm{e}^{(-0.36 \times \mathrm{N})} ; \mathrm{r}^{2}=0.99 .
\end{gathered}
$$

The asymptotic values of the equations (71.7 and 51.8\%) indicate the maximal DM and NDF digestibilities when $\mathrm{N}$ content of the diet was not limiting for the ruminal environment, respectively. The $95 \%$ confidence interval of the asymptotes indicates that DM and NDF digestibilities were reduced when the $\mathrm{N}$ content of the diet was $<20.7$ and $18.7 \mathrm{~g} / \mathrm{kg}$ of DM, respectively (Figure 2a). Apparent $\mathrm{N}$ digestibility (Figure $2 \mathrm{~b}$ ) increased in a curvilinear manner $\left(\mathrm{Ndig}=100.8-93.4 \times \mathrm{e}^{(0.39 \mathrm{~N})} ; \mathrm{r}^{2}=0.94\right)$, but the improvement over the linear relationship was rather small $\left(\mathrm{Ndig}=26.0+1.52 \mathrm{~N} ; \mathrm{r}^{2}=0.92\right)$.

The PUN concentration increased exponentially (Figure 3) with increasing $\mathrm{N}$ content of the diet, whereas there was a linear relationship between total UN and UUN (Figure 4).

$$
\mathrm{UUN}(\mathrm{g} / \mathrm{d})=-13.7+0.90 \times \mathrm{UN} ; \mathrm{r}^{2}=0.99
$$

where UUN is urinary urea $\mathrm{N}(\mathrm{g} / \mathrm{d})$ and UN is urinary $\mathrm{N}(\mathrm{g} / \mathrm{d})$. Urinary urea $\mathrm{N}$ excretion ranged from 1.2 to $95.6 \mathrm{~g}$ of N/d (Figure 4), the equivalent to 2.1 to $47.0 \%$ of the $\mathrm{N}$ intake. Figure 5 shows the partition of the $\mathrm{N}$ excreted between feces and urine. The percentage of $\mathrm{N}$ 


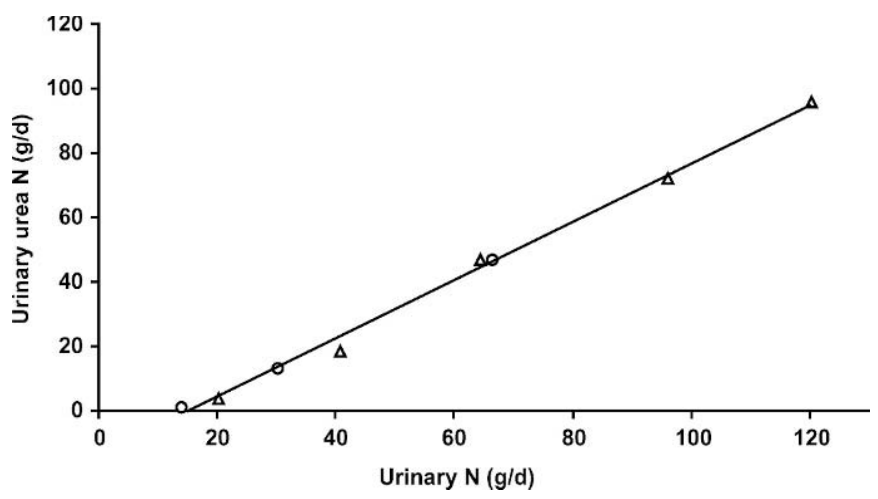

Figure 4. Relationship between total urinary N (UN; g/d) and urinary urea N (UUN; g/d) excretion in Holstein heifers. Each symbol represents the mean of 4 observations (experiment $1, \triangle$; experiment 2 , $)$. The linear regression for both experiments was UUN $=-13.7$ $+0.90 \times \mathrm{UN} ; \mathrm{r}^{2}=0.99 . \mathrm{SEM}=0.99 \mathrm{~g} / \mathrm{d}$.

excreted in feces decreased from 70 to $30 \%$, while urine increased from 30 to $70 \%$ over the range of dietary $\mathrm{N}$ studied.

Distribution of $\mathrm{N}$ in the urine and feces of the animals in experiment 1 is shown in Table 2 . The UUN increased with $\mathrm{N}$ intake (Table $2 ; P<0.001$ ) and was the primary urinary $\mathrm{N}$ component, except when heifers were fed the lowest level of N. In this case, PD, a metabolite of ruminal bacteria, were the main $\mathrm{N}$ component, accounting for $27 \%$ of the $\mathrm{N}$ excreted. The PD excretion was not affected $(P<0.32)$ by the $\mathrm{N}$ content of the diet and averaged $6.1 \mathrm{~g}$ of $\mathrm{N} / \mathrm{d}$. Creatinine $\mathrm{N}$ excretion was not affected ( $P=0.88$; Table 2$)$ by the diet, but increased linearly over time (period effect; $P<0.001$ ) with increasing BW and averaged $9.5 \mathrm{mg}$ of creatinine $\mathrm{N} / \mathrm{kg}$ of BW. Urinary ammonia excretion was linearly $(P<0.02)$ related to $\mathrm{N}$ intake, although it represented a small fraction of the total $\mathrm{N}$ excretion (Table 2$)$. No differences $(P$

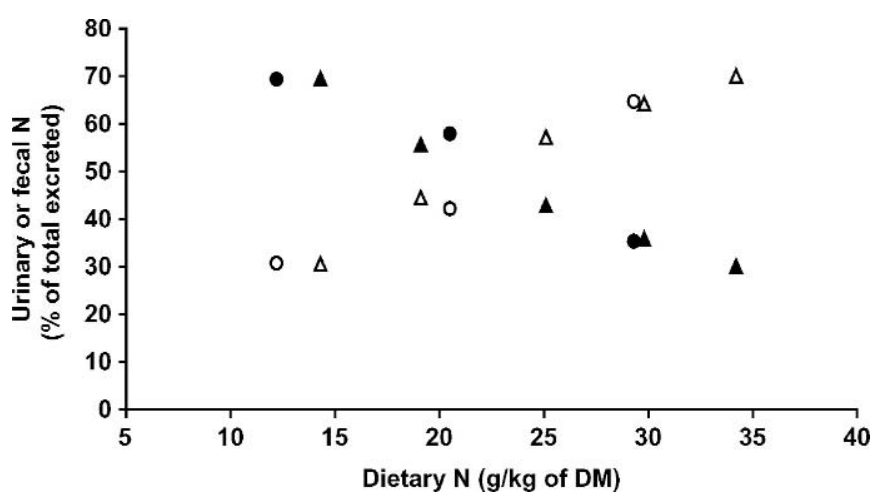

Figure 5. Effect of dietary $\mathrm{N}(\mathrm{g} / \mathrm{kg}$ of $\mathrm{DM})$ on the route of $\mathrm{N}$ excretion in Holstein heifers. Each symbol (open, urine; solid, feces) represents the mean of 4 observations (experiment $1, \triangle \mathbf{A}$; experiment $2, \bigcirc$ ). $\mathrm{SEM}=1.7 \%$ for both urinary and fecal $\mathrm{N}$.
$>0.05$ ) were found in the total fecal $\mathrm{N}$, fecal $\mathrm{N}$ bound to fiber (NDF and ADF), or fecal nucleic acids $\mathrm{N}$ excretion among diets, but fecal ammonia excretion increased $(P$ $<0.004$ ) linearly with increasing dietary $\mathrm{N}$ content (Table 2 ).

\section{DISCUSSION}

The experimental diets provided a similar amount of energy for growth, but increasing the $\mathrm{N}$ content of the diets increased the amount of $\mathrm{N}$ retained. The Cornell Net Carbohydrate Protein System successfully predicted the $\mathrm{N}$ requirement to maximize $\mathrm{N}$ retention given the energy content of the diets fed, but failed to estimate the $\mathrm{N}$ retained when $\mathrm{N}$ was deficient (Table 1; Figure 1). Most nutritional models have been designed to maximize productivity, and several 'safety factors' are usually included. However, the efficiency of dietary $\mathrm{N}$ for growth decreases dramatically as requirements are met and excess $\mathrm{N}$ is excreted mainly in urine. Some feeding systems, such as the Dutch DVE system, have been introduced with the aim to control avoidable $\mathrm{N}$ losses to the environment (Tamminga et al., 1994). A recent federal review of the National Ambient Air Quality Standards (U.S. E.P.A., 1997) has resulted in a new standard for particulate matter, which will include ammonia and will accelerate the need for accurate estimation and control of ammonia emission.

One of the limitations of the currently available diet evaluation and formulation models is that the amount of $\mathrm{N}$ recycled to the rumen and its contribution to microbial production are not accurately predicted. For example, although the amount of $\mathrm{N}$ recycled to the total gastrointestinal tract was not different among the diets fed to animals in experiment 1 (Marini and Van Amburgh, 2003), the contribution of recycled $\mathrm{N}$ to microbial protein decreased from $20 \%$ to only $4 \%$ in the range of $\mathrm{N}$ intake studied. This ability of ruminants to recycle $\mathrm{N}$ to the gastrointestinal tract instead of excreting it into the environment could prove very useful in maintaining performance while at the same time reducing the amount of $\mathrm{N}$ fed.

A depression in DM and fiber digestibility was observed when the $\mathrm{N}$ content of the diet was reduced, similar to that reported by Bandyk et al. (2001). Cellulolytic ruminal bacteria require ammonia as a $\mathrm{N}$ source and are unable to ferment fiber when ammonia is depleted (Bryant, 1973). The depression observed in fiber digestibility was likely due to low ruminal ammonia and not to a low ruminal $\mathrm{pH}$ (data not shown; Marini and Van Amburgh, 2003). However, based on PD data, microbial yield was not affected by the $\mathrm{N}$ content of the diet. The increase in $\mathrm{N}$ digestibility relates to a more or less constant amount of $\mathrm{N}$ excreted in the feces (the so-called 
NITROGEN EXCRETION IN HOLSTEIN HEIFERS

Table 2. Effect of dietary $\mathrm{N}$ concentration on the partition of $\mathrm{N}$ in urine and feces.

\begin{tabular}{|c|c|c|c|c|c|c|c|c|}
\hline \multirow[b]{2}{*}{ Item } & \multicolumn{5}{|c|}{ Treatment } & \multirow[b]{2}{*}{ SEM } & \multicolumn{2}{|c|}{$P$} \\
\hline & $\mathrm{E} 1 \mathrm{D} 1^{1}$ & E1D2 & E1D3 & E1D4 & E1D5 & & Linear & Quadratic \\
\hline BW, kg & 267.9 & 266.7 & 266.8 & 269.3 & 266.4 & 3.60 & 0.930 & 0.980 \\
\hline $\mathrm{N}$ intake, $\mathrm{g} / \mathrm{d}$ & 87.6 & 110.4 & 147.5 & 178.7 & 203.5 & 5.10 & 0.001 & 0.870 \\
\hline Total fecal N, g/d & 46.3 & 49.6 & 49.2 & 52.0 & 50.3 & 1.22 & 0.210 & 0.760 \\
\hline NDF N,$^{2} \mathrm{~g} / \mathrm{d}$ & 6.9 & 7.7 & 6.7 & 6.5 & 6.3 & 0.45 & 0.470 & 0.690 \\
\hline $\mathrm{ADF} \mathrm{N},{ }^{3} \mathrm{~g} / \mathrm{d}$ & 5.5 & 5.0 & 4.9 & 4.9 & 5.0 & 0.11 & 0.680 & 0.500 \\
\hline Nucleic acid N, g/d & 3.4 & 3.4 & 2.8 & 3.2 & 2.5 & 0.20 & 0.094 & 0.882 \\
\hline Ammonia N, g/d & 1.8 & 2.8 & 3.1 & 3.8 & 3.6 & 0.16 & 0.004 & 0.210 \\
\hline Total urinary $\mathrm{N}, \mathrm{g} / \mathrm{d}$ & 21.7 & 36.1 & 68.7 & 94.3 & 120.8 & 5.88 & 0.001 & 0.040 \\
\hline Urea N, g/d & 5.2 & 15.0 & 50.4 & 70.5 & 95.8 & 5.75 & 0.001 & 0.350 \\
\hline Non-urea N, g/d & 16.4 & 21.0 & 18.3 & 23.8 & 25.0 & 1.37 & 0.010 & 0.810 \\
\hline Ammonia N, g/d & 0.1 & 0.3 & 0.4 & 0.3 & 0.3 & 0.07 & 0.020 & 0.070 \\
\hline Creatinine $\mathrm{N}, \mathrm{g} / \mathrm{d}$ & 2.5 & 2.7 & 2.6 & 2.5 & 2.4 & 0.22 & 0.880 & 0.500 \\
\hline $\mathrm{PD} \mathrm{N},{ }^{4} \mathrm{~g} / \mathrm{d}$ & 5.5 & 5.8 & 7.1 & 6.2 & 5.8 & 0.36 & 0.320 & 0.480 \\
\hline
\end{tabular}

${ }^{1} \mathrm{E} i \mathrm{D} 1$ = Diet $i$ in Experiment 1; E1D1 through E1D5: 14.4, 19, 25.1, 29.8, and $34.2 \mathrm{~g}$ of N/kg of DM, respectively.

${ }^{2} \mathrm{NDF} \mathrm{N}=$ Neutral detergent insoluble $\mathrm{N}$.

${ }^{3} \mathrm{ADF} \mathrm{N}=$ Acid detergent insoluble $\mathrm{N}$.

${ }^{4} \mathrm{PD} \mathrm{N}=$ Purine derivatives $\mathrm{N}$.

metabolic fecal N; NRC, 2001). Increasing the $\mathrm{N}$ content of the diet results in an increasing dilution of the metabolic fecal $\mathrm{N}$, yielding a greater apparent digestibility for $\mathrm{N}$.

Increasing the $\mathrm{N}$ content of the diet increased the UN excretion, in absolute terms and as a percentage of the total $\mathrm{N}$ excreted, and urea $\mathrm{N}$ made up for most (90\%) of the additional loss of $\mathrm{N}$ in the urine. Urea $\mathrm{N}$ accounted 2.1 to $47 \%$ of the $\mathrm{N}$ ingested in the range of dietary $\mathrm{N}$ studied. These data demonstrate that as the $\mathrm{N}$ supply decreases, the efficiency with which $\mathrm{N}$ is used for different metabolic processes increased significantly.

Creatinine $\mathrm{N}$ excretion was independent of the $\mathrm{N}$ content of the diet but increased as the animals gained weight. Thus, creatinine can be used successfully as a marker to estimate urinary output in trials where total collection is difficult or inconvenient (Vagnoni and Broderick, 1997). The route of $\mathrm{N}$ excretion is important because urinary urea and PD seem to be the major sources of ammonia and nitrous oxide emitted from manure (Van Horn et al., 1994; Flessa et al., 1996), and UUN has been linearly related to ammonia emissions (Krober et al., 2000). Urinary urea is hydrolyzed to ammonia in $<24 \mathrm{~h}$, both in grazing (Petersen et al., 1998) and confined animals (James et al., 1999), whereas the $\mathrm{N}$ present in feces is relatively stable (Petersen et al., 1998) because most of it is feed or bacterial N (Mason, 1969). Furthermore, the reduction in $\mathrm{N}$ excretion, combined with a reduction in fiber digestibility, increases the C:N ratio of the manure of animals fed low CP diets. High C:N ratios have been related to a decrease in $\mathrm{N}$ losses, both as ammonia and nitrous oxide (Kulling et al., 2001). Dietary manipulation of $\mathrm{N}$ utilization is the most attrac- tive strategy used to reduce ammonia emissions because a large proportion of the $\mathrm{N}$ in manure is usually volatilized before it reaches a storage facility before any other measures can be implemented (Muck and Steenhuis, 1980). It has been shown that reducing the input of dietary $\mathrm{N}$ had a 7-fold greater effect on whole farm $\mathrm{N}$ efficiency than strategies that reduce $\mathrm{N}$ loss at the manure storage level (Kohn et al., 1997). Although the latter technology usually requires a substantial capital investment and a long-time commitment, dietary changes can be implemented immediately and often reduce feed costs (Kohn et al., 1997).

\section{CONCLUSIONS}

Holstein heifers fed low $\mathrm{N}$ diets were able to maintain adequate growth rates and $\mathrm{N}$ retention, similar to industry recommendations, while reducing the amount of $\mathrm{N}$ excreted. Results from this study showed that by changing the dietary $\mathrm{N}$ content of the diet, the partition of the $\mathrm{N}$ excreted between urine and feces can be manipulated. Reducing dietary $\mathrm{N}$ content resulted in a reduction in UN excretion, mainly as urinary urea, which has been shown to be rapidly converted into ammonia and nitrous oxide. However, more research is needed before this type of diet is recommended for growing heifers, because of possible changes in body composition that may affect future milk production and performance.

\section{ACKNOWLEDGMENTS}

We thank Laura Lintault for her assistance with sample collection and analysis and Greg Albrecht for his comments on the manuscript. 


\section{REFERENCES}

AOAC. 1990. Official Methods of Analysis. 15th ed. Assoc. Official Anal. Chem., Int., Arlington, VA.

Bandyk, C. A., R. C. Cochran, T. A. Wickersham, E. C. Titgemeyer, C. G. Farmer, and J. J. Higgins. 2001. Effect of ruminal vs. postruminal administration of degradable protein on utilization of lowquality forage by beef steers. J. Anim. Sci. 79:225-231.

Bryant, M. P. 1973. Nutritional requirements of the predominant rumen cellulolytic bacteria. Fed. Proc. 32:155-163.

Castillo, A. R., E. Kebreab, D. E. Beever, J. H. Barbi, J. D. Sutton, H. C. Kirby, and J. France. 2001. The effect of protein supplementation on nitrogen utilization in lactating dairy cows fed grass silage diets. J. Anim. Sci. 79:247-253.

Chaney, A. L., and E. P. Marbach. 1962. Modified reagents for determination of urea and ammonia. Clin. Chem. 8:130-132.

Cole, N. A., L. W. Greene, F. T. McCollum, T. Montgomery, and K. McBride. 2003. Influence of oscillating dietary crude protein concentration on performance, acid-base balance, and nitrogen excretion of steers. J. Anim. Sci. 81:2660-2668.

Drackley, J. K., T. R. Overton, and G. N. Douglas. 2001. Adaptations of glucose and long-chain fatty acid metabolism in liver of dairy cows during the periparturient period. J. Dairy Sci. 84: E100-E112.

Economic Research Service. 2002. Livestock and Poultry Situation and Outlook LDP-M-92. USDA, Washington, DC.

Flessa, H., P. Dorsch, F. Beese, H. Koning, and A. F. Bouwman. 1996. Influence of cattle wastes on nitrous oxide and methane fluxes in pasture land. J. Environ. Qual. 25:1366-1370.

Flodin, N. W., P. H. Morgan, and L. P. Mercer. 1977. The problem of human protein requirements: Some kinetic and metabolic considerations. Med. Hypotheses 3:94-110.

Fox, D. G., L. O. Tedeschi, T. P. Tylutki, J. B. Russell, M. E. Van Amburgh, L. E. Chase, A. N. Pell, and T. R. Overton. 2004. The Cornell Net Carbohydrate and Protein System model for evaluating herd nutrition and nutrient excretion. Anim. Feed Sci. Technol. 112:29-78

Fox, D. G., T. P. Tylutki, M. E. Van Amburgh, L. E. Chase, A. N. Pell, T. R. Overton, C. N. Rasmussen, L. O. Tedeschi, and V. N. Durbal. 2000. The Net Carbohydrate and Protein System for evaluating herd nutrition and nutrient excretion: Model documentation. Animal Science Dep. Mimeo 212, Cornell University, Ithaca, NY.

Frank, B., M. Persson, and G. Gustafsson. 2002. Feeding dairy cows for decreased ammonia emission. Livest. Prod. Sci. 76:171-179.

Han, E. N., E. Bauce, and F. Trempe-Bertrand. 2000. Development of the first-instar spruce budworm (Lepidoptera: Tortricidae). Ann. Entomol. Soc. Am. 93:536-540.

IPCC (Intergovernmantal Panel on Climate Change). 1996. Climate Change. The Science of Climate Change. J. T. Houghton, G. J. Jenkins, and J. J. Ephraums, ed. Cambridge University Press, Cambridge, UK.

James, T., D. Meyer, E. Esparza, E. J. Depeters, and H. Perez-Monti. 1999. Effects of dietary nitrogen manipulation on ammonia volatilization from manure from Holstein heifers. J. Dairy Sci. 82:2430-2439.

Johnson, D. E., G. M. Ward, and J. Torrent. 1992. The environmental impact of bovine somatotropin use in dairy cattle. J. Environ. Qual. 21:157-162.

Kohn, R. A., S. Dou, J. D. Ferguson, and R. C. Boston. 1997. A sensitivity analysis of nitrogen loss from dairy farms. J. Environ. Manage. 50:417-428.

Krober, T. F., D. R. Kulling, H. Menzi, F. Sutter, and M. Kreuzer. 2000. Quantitative effects of feed protein reduction and methionine on nitrogen use by cows and nitrogen emission from slurry. J. Dairy Sci. 83:2941-2951.

Kulling, D. R., H. Menzi, T. F. Krober, A. Neftel, F. Sutter, P. Lishcer, and M. Kreuzer. 2001. Emissions of ammonia, nitrous oxide and methane from different types of dairy manure during storage as affected by dietary protein content. J. Agric. Sci. 137:235-250.

Marini, J. C., and M. E. Van Amburgh. 2003. Nitrogen metabolism and recycling in Holstein heifers. J. Anim. Sci. 81:545-552.

Marsh, W. H., B. Fingerhut, and E. Kirsch. 1957. Determination of urea with the diacetyl method and an automatic dialyzing apparatus. Am. J. Clin. Pat. 28:681-688.

Mason, V. 1969. Some observations on the distribution and origin of nitrogen in sheep feces. J. Agric. Sci. 73:99-111.

Mercer, L. P., H. E. May, and S. J. Dodds. 1989. The determination of nutritional requirements in rats: Mathematical modeling of sigmoideal, inhibited nutrient response curves. J. Nutr. 119:14651471.

Muck, R. E., and T. S. Steenhuis. 1980. N losses in free stall dairy barns. Livestock Waste: A Renewable Resource. In Proceedings 4th Int. Symp. on Livestock Wastes. ASAE, St. Joseph, MI.

Nicholson, R. J., J. Webb, and A. Moore. 2002. A review of the environmental effects of different livestock manure storage systems, and a suggested procedure for assigning environmental ratings. Biosyst. Eng. 81:363-377.

NRC. 2001. Nutrient Requirements of Dairy Cattle, 7th rev. ed. Natl. Acad. Press, Washington, DC.

Petersen, S. O., S. G. Sommer, O. Aaes, and K. Soegaard. 1998. Ammonia losses from urine and dung of grazing cattle: Effect of $\mathrm{N}$ intake. Atmos. Environ. 32:295-300.

Pierce, W. C., and E. L. Haenisch. 1940. Quantitative Analysis, 2nd ed. John Wiley and Sons, Inc., New York, NY.

Shingfield, K. J., and N. W. Offer. 1999. Simultaneous determination of purine metabolites, creatinine and pseudouridine in ruminant urine by reversed-phase high-performance liquid chromatography. J. Chromatogr. Biomed. Sci. Appl. 723:81-94.

Sillence, M. N., M. L. Matthews, T. W. Badran, and G. G. Pegg. 2000 Effects of clenbuterol on growth in underfed cattle. Aust. J. Agric. Res. 51:401-406.

Swensson, C., and S. Gustafsson. 2002. Characterization of influence of manure handling system and feeding on the level of ammonia release using a simple method in cow houses. Acta Agric. Scand. A 52:49-56.

Tamminga, S., W. M. Vanstraalen, A. P. J. Subnel, R. G. M. Meijer, A. Steg, C. J. G. Wever, and M. C. Blok. 1994. The Dutch protein evaluation system. The DVE/OEB system. Livest. Prod. Sci. 40:139-155.

Tomlinson, D. L., R. E. James, G. L. Bethard, and M. L. McGilliard. 1997. Influence of undergradability of protein in the diet on intake, daily gain, feed efficiency, and body composition of Holstein heifers. J. Dairy Sci. 80:943-948.

US Environmental Protection Agency. 1997. National Ambient Air Quality Standards for particulate matter; final rule. Federal Register Part II. 40 CFR Part 50 Vol. 62, No. 138, Friday, July 18, 1997.

Vagnoni, D. B., and G. A.Broderick. 1997. Effects of supplementation of energy or ruminally undegraded protein to lactating cows fed alfalfa hay or silage. J. Dairy Sci. 80:1703-1712.

Van Horn, H. H., A. C. Wilkie, W. J. Powers, and R. A. Nordstedt. 1994. Components of dairy manure management systems. J. Dairy Sci. 77:2008-2030.

Van Soest, P. J. 1994. Nutritional Ecology of the Ruminant, 2nd ed. Cornell University Press. Ithaca, NY.

Van Soest, P. J., J. B. Robertson, and B. A. Lewis. 1991. Methods for dietary fiber, neutral detergent fiber, and nonstarch polysaccharides in relation to animal nutrition. J. Dairy Sci. 74:3583-3597.

Wulf, S., M. Maeting, and J. Clemens. 2002. Application technique and slurry co-fermentation effects on ammonia, nitrous oxide, and methane emissions after spreading. I. Ammonia volatilization. J. Environ. Qual. 31:1795-1801.

Zinn, R. A., and F. N. Owens. 1986. A rapid procedure for purine measurements and its use for estimating net ruminal protein synthesis. Can. J. Anim. Sci. 66:157-166. 